\section{HUKUM MENDONORKAN DAN MENTRANSPLANTASI ANGGOTA TUBUH DALAM ISLAM}

\section{Haswir}

Fakultas Syari'ah dan Ilmu Hukum UIN Suska Riau

\section{Abstract}

The Law of Donating and Transplanting Human Organs in Islam: Issue about buman organ donation and transplantation cause problems, as can be seen from various aspects, i.e. aspects of worship, muamalah and jinayah. Many questions surrounding this issue are waiting for answers from the view of Islamic law. It is obviously known that the transplantation of buman organs and tissue is a useful medical treatment for patients with impaired organ function. This way is the best alternative therapies to help patients with organ failure or dysfunction, because the results are more satisfactory. In general, legitimacy of transplants and organ donation refers to the goals of buman creation, namely to be caliph in the world (khalifah fi al-ardh). It is technically analyzed with ta'lili and istishlabi reasoning. In ta'liliyah, permissibility of human organ transplantation and donation has been analogous to the possibility to give forgiveness and take diyat in qisas cases. In istishlabiyah, it is assessed based on the concept of mashlabah, namely something returned to the upholding of human life in absolute. The buman need against transplantation seems irresistible. Therefore, which opinion that would be used is up to the buman needs with the consideration of mashlahah.

Keywords: Transplantation, Donation, Organ, Islamic Law.

\section{Pendahuluan}

Kemajuan ilmu dan teknologi kedokteran telah menimbulkan perubahan besar dalam kehidupan sosial, terutama dalam hal penanganan berbagai macam penyakit yang pada mulanya sulit diobati atau ditanggulangi. Dengan adanya kemajuan ilmu dan teknologi kedokteran, telah dilakukan berbagai terobosan dalam bidang pengobatan dan hasilnya semakin memberikan kepuasan konsumen.
Kemajuan dunia kedokteran ini tidak lepas dari semakin meningkatnya jenis penyakit sehingga mendorong pakar kesehatan untuk melakukan penelitian dan eksperimen serta membuat berbagai teknologi pendukungnya, sehingga penyakit yang dulunya sulit diobati justru menjadi mudah diobati bahkan mendekati kesembuhan yang sempurna.

Dewasa ini ilmu pengetahuan dan teknologi di bidang kedokteran berkembang dengan pesat. Salah satunya adalah kemajuan dalam teknik transplantasi organ. Transplantasi organ merupakan teknologi medis untuk penggantian organ tubuh pasien yang tidak berfungsi dengan organ individu lain. Sejak kesuksesan transplantasi yang pertama kali berupa ginjal dari donor kepada pasien gagal ginjal pada tahun 1954, perkembangan di bidang transplantasi maju dengan pesat. Kemajuan ilmu dan teknologi memungkinkan pengawetan organ, penemuan obat-obatan anti penolakan yang semakin baik sehingga berbagai organ dan jaringan dapat ditransplantasikan. Dalam beberapa kepustakaan disebutkan bahwa transplantasi organ sudah dilakukan sejak tahun 600 SM, dimana saat itu Susruta dari India telah melakukan transplantasi kulit. ${ }^{1}$

Seorang dokter di Cina, Pien Chi'ao melaporkan telah melakukan pertukaran jantung antara seorang laki-laki dengan semangat kuat tetapi keinginan lemah dengan seorang laki-laki yang semangatnya lemah tapi memiliki keinginan yang kuat dalam berusaha, untuk mencapai keseimbangan dalam hidup. Gereja Katolik mencatat pada abad III, seorang pastur melakukan transplantasi kaki pada seorang umatnya dengan kaki dari jenazah seorang Ethiopia. John Hunter (1728-1793) dianggap sebagai pioneer dalam bedah eksperimental termasuk transplantasi atas keberhasilannya dalam membuat kriteria teknik bedah untuk menghasilkan jaringan transplantasi yang tumbuh di tempat yang baru. Namun angka

${ }^{1}$ Teresa,L. Nilai Etika Transplantasi Organ. Available at: http://www./maranatha.com/transplantasi (Accessed: May 30, 2008). 
keberhasilan dari transplantasi tersebut masih minimal karena tidak didukung dengan adanya sistem golongan darah dan bistokompatibilitas. Seiring dengan ditemukannya golongan darah sistem $\mathrm{ABO}$ dan Rhesus oleh Wiener dan Landsteiner pada abad XX, angka keberhasilan transplantasi mengalami peningkatan. ${ }^{2}$

Ilmu transplantasi modern semakin berkembang dengan ditemukannya metode-metode pencangkokan, misalnya; [a] Pencangkokan arteria mammaria interna di dalam operasi lintas koroner oleh Dr. George E Green; [b] Pencangkokan jantung, dari jantung kera kepada manusia oleh Dr. Cristian Bernard, walaupun kemudian resipiennya kemudian meninggal dalam waktu 18 hari; [c] Pencangkokan sel-sel substansia nigra dari bayi yang meninggal ke penderita Parkinson oleh Dr. Andreas Bjorknlund; [d] Pencangkokan ginjal; [e] Pencangkokan hati; [f] Pencangkokan sumsum tulang; dan [g]Pencangkokan pankreas. ${ }^{3}$

Sampai saat ini penelitian tentang transplantasi masih terus dilakukan. Permintaan untuk transplantasi organ terus mengalami peningkatan melebihi ketersediaan organ donor yang ada. Di China, pada tahun 1999 tercatat hanya 24 transplantasi hati, namun tahun 2000 jumlahnya mencapai 78. Sedangkan tahun 2003 angkanya bertambah hingga 356. Jumlah tersebut semakin meningkat pada tahun 2004 yaitu 507 kali transplantasi. Tidak hanya hati, jumlah transplantasi keseluruhan organ di China memang meningkat sangat drastis. Setidaknya telah terjadi tiga kali lipat melebihi Amerika Serikat. Ketidakseimbangan antara jumlah pemberi organ dengan penerima organ hampir terjadi di seluruh dunia. ${ }^{4}$

${ }^{2}$ Suprapti, S.R. Etika Kedokteran Indonesia.Transplantasi. (Jakarta: Yayasan Bina Pustaka Sarwono Prawirohardjo, 2001), Edisi ke-2.

3 Anonim Organ Transplant, Available at: http://www.en.wikipedia.com (Accessed: May 27, 2008)

4 Triana N. Menengok Transplantasi Organ di China, Available at: ttp://www.jurnalnasional.com (Accessed: May 29,2008)
Diakui atau tidak, persoalan transplantasi ini telah menyentuh wilayah agama, sebab tidak tertutup kemungkinan akan berlaku dan menjadi kebutuhan pula dalam masyarakat Islam. Pertanyaan yang sering muncul adalah apakah manusia memiliki dirinya secara mutlak sehingga boleh ia pergunakan untuk apapun, atau apakah tubuh itu titipan Allah yang tidak boleh dipergunakan selain untuk hal-hal yang diizinkan oleh Allah? Atau tubuh manusia itu titipan Allah namun diberiNya wewenang untuk melakukan berbagai hal yang dapat memberi manfaat luas? Persoalan mendonorkan dan mentransplantasi anggota tubuh memang menimbulkan problematika, karena dapat dilihat dari berbagai aspek, yaitu aspek ibadah, muamalah atau jinayah. Ketika mendonorkan anggota tubuh dapat dianggap ibadah, kemanakah tempat analoginya, bagaimana batasannya dan apakah landasan syar'inya? Begitu juga jika mendonorkan anggota tubuh dapat digolongkan muamalah, bolehkah sebagaimana bolehnya non komersial? Demikian pula jika mendonorkan anggota tubuh dianggap jinayah, bagaimana jika dalam perbuatan itu banyak manfaatnya dan dapat diminimalisir mudharatnya? dan banyak lagi pertanyaan yang beredar seputar masalah ini yang menunggu jawabannya dari sisi hukum Islam.

\section{Pengertian Transplantasi}

Transplantasi atau pencangkokan organ tubuh adalah pemindahan organ tubuh tertentu yang mempunyai daya hidup yang sehat, dari seseorang untuk menggantikan organ tubuh yang tidak sehat atau tidak berfungsi dengan baik milik orang lain. Orang yang anggota tubuhnya dipindahkan disebut donor (pen-donor), sedang yang menerima disebut repisien. Cara ini merupakan solusi bagi penyembuhan organ tubuh tersebut karena penyembuhan atau pengobatan dengan prosedur medis biasa tidak ada harapan kesembuhannya.

Transplantasi organ dan jaringan tubuh manusia merupakan tindakan medik yang sangat bermanfaat bagi pasien dengan ganguan 
fungsi organ tubuh yang berat. Ini adalah terapi alternatif yang merupakan upaya terbaik untuk menolong pasien dengan kegagalan organnya, karena hasilnya lebih memuaskan dan hingga dewasa ini terus berkembang dalam dunia kedokteran, namun tindakan medik ini tidak dapat dilakukan begitu saja, karena masih harus dipertimbangkan dari segi non medik, yaitu dari segi agama, hukum, budaya, etika dan moral.

Kini telah dikenal beberapa jenis transplantasi atau pencangkokan, baik berupa sel, jaringan maupun organ tubuh yaitu sebagai berikut; [a] transplantasi autologus, yaitu perpindahan dari satu tempat ketempat lain dalam tubuh itu sendiri, yang dikumpulkan sebelum pemberian kemoterapi; [b] transplantasi alogenik, yaitu perpindahan dari satu tubuh ketubuh lain yang sama spesiesnya, baik dengan hubungan keluarga atau tanpa hubungan keluarga; [c] transplantasi singenik, yaitu perpindahan dari satu tubuh ketubuh lain yang identik, misalnya pada gambar identik; [d] transplantasi xenograft, yaitu perpindahan dari satu tubuh ketubuh lain yang tidak sama spesiesnya. Organ atau jaringan tubuh yang akan dipindahkan dapat diambil dari donor yang hidup atau dari jenazah orang yang baru meninggal dimana meninggal sendiri didefinisikan kematian batang otak. Organ-organ yang diambil dari donor hidup seperti : kulit ginjal sumsum tulang dan darah (transfusi darah). Organ-organ yang diambil dari jenazah adalah jantung, hati, ginjal, kornea, pancreas, paru-paru dan sel otak. Dalam 2 dasawarsa terakhir telah dikembangkan tehnik transplantasi seperti transplantasi arteria mamaria interna dalam operasi lintas koroner oleh George E. Green. dan Parkinson ${ }^{5}$

Aspek Legalitas Transplantasi Organ Tubuh Dalam UndangUndang

5 http://httpyasirblogspotcom.blogspot.com/2009/05/transplantasi-organdan-jaringan-tubub.
Dalam aturan hukum yang berlaku di Indonesia, transplantasi dan donor organ ini telah diatur melalui PP Nomor 18 Tahun 1981 Tentang Bedah Mayat Klinis dan Bedah Mayat Anatomis serta Transplantasi Alat dan atau Jaringan Tubuh Manusia. Pasal tentang transplantasi adalah sebagai berikut:

\section{Pasal 1}

a. Alat tubuh manusia adalah kumpulan jaringan-jaringa tubuh yang dibentuk oleh beberapa jenis sel dan mempunyai bentuk serta faal (fungsi) tertentu untuk tubuh tersebut.

b. Jaringan adalah kumpulan sel-sel yang mempunyai bentuk dan faal (fungsi) yang sama dan tertentu.

c. Transplantasi adalah rangkaian tindakan kedokteran untuk pemindahan dan atau jaringan tubuh manusia yang berasal dari tubuh orang lain dalam rangka pengobatan untuk menggantikan alat dan atau jaringan tubuh ynag tidak berfungsi dengan baik.

d. Donor adalah orang yang menyumbangkan alat atau jaringan tubuhnya kepada orang lain untuk keperluan kesehatan.

e. Meninggal dunia adalah keadaan insani yang diyakini oleh ahli kedokteran yang berwenang bahwa fungsi otak, pernafasan dan atau denyut jantung seseorang telah berhenti. ${ }^{6}$

Ayat (g) mengenai definisi meninggal dunia kurang jelas, maka IDI dalam seminar nasionalnya mencetuskan fatwa tentang masalah mati yaitu bahwa seseorang dikatakan mati bila fungsi spontan pernafasan dan jantung telah berhenti secara pasti atau irreversible, atau terbukti telah terjadi kematian batang otak.

\section{Pasal 10}

1. Transplantasi alat dan atau jaringan tubuh manusia dilakukan dengan memperhatikan ketentuan-ketentuan sebagaimana dimaksud dalam Pasal 2 huruf a dan huruf b.

2. Tatacara transplantasi alat dan atau jaringan tubuh manusia diatur oleh Menteri Kesehatan.

\footnotetext{
${ }^{6}$ Peraturan Pemerintah Nomor 18 Tahun 1981.
} 


\section{Pasal 11}

1. Transplantasi organ dan jaringan tubuh hanya boleh dilakukan oleh dokter yang ditunjuk oleh mentri kesehatan.

2. Transplantasi alat dan jaringan tubuh manusia tidak boleh dilakukan oleh dokter yang merawat atau mengobati donor yang bersangkutan.

\section{Pasal 12}

Penentuan saat mati ditentukan oleh 2 orang dokter yang tudak ada sangkut paut medik dengan dokter yang melakukan transplantasi.

\section{Pasal 13}

Persetujuan tertulis sebagaimana dimaksudkan yaitu dibuat diatas kertas materai dengan 2(dua) orang saksi.

$$
\text { Pasal } 14
$$

Pengambilan alat atau jaringan tubuh manusia untuk keperluan transplantasi atau bank mata dari korban kecelakaan yang meninggal dunia,dilakukan dengan persetujuan tertulis dengan keluarga terdekat.

\section{Pasal 15}

1. Sebelum persetujuan tentang transplantasi alat dan jaringan tubuh manusia diberikan oleh donor hidup, calon donor yang bersangkutan terlebih dahulu diberitahu oleh dokter yang merawatnya, termasuk dokter konsultan mengenai operasi, akibat-akibatnya, dan kemungkinan-kemungkinan yang terjadi.

2. Dokter sebagaimana dimaksud dalam ayat (1) harus yakin benar, bahwa calon donor yang bersangkutan telah meyadari sepenuhnya arti dari pemberitahuan tersebut.

Pasal 16

Donor atau keluarga donor yang meninggal dunia tidak berhak dalam kompensasi material apapun sebagai imbalan transplantasi.

Pasal 17

Dilarang memperjual belikan alat atau jaringan tubuh manusia.

Pasal 18
Dilarang mengirim dan menerima alat dan jaringan tubuh manusia dan semua bentuk ke dan dari luar negeri.

Selanjutnya dalam UU No.23 tahun 1992 tentang kesehatan dicantumkan beberapa pasal tentang transplantasi sebagai berikut:

\section{Pasal 33}

1. Dalam penyembuhan penyakit dan pemulihan kesehatan dapat dilakukan transplantasi organ dan jaringan tubuh, transfusi darah, implan obat dan alat kesehatan, serta bedah plastik dan rekontruksi.

2. Transplantasi organ dan jaringan serta transfusi darah sebagaimana dimaksud dalam ayat (1) dilakukan hanya untuk tujuan kemanusiaan yang dilarang untuk tujuan komersial.

Pasal 34

1. Transplantasi organ dan jaringan tubuh hanya dapat dilakukan oleh tenaga kesehatan yang mempunyai keahlian dan kewenangan untuk itu dan dilakukan disaran kesehatan tertentu.

2. Pengambilan organ dan jaringan tubuh dari seorang donor harus memperhatikan kesehatan donor yang bersangkutan dan ada persetujuan ahli waris atau keluarganya.

3. Ketentuan mengenai syarat dan tata cara penyelenggaraan transplantasi sebagaimana yang dimaksud dalam ayat (1) dan ayat (2) ditetapkan dengan peraturan pemerintah. ${ }^{7}$

Pelanggaran terhadap ketentuan Pasal 33 ayat (2) ini yaitu bagi siapa pun yang melakukan perbuatan dengan tujuan komersial dalam transplantasi organ tubuh atau jaringan tubuh dan atau transfusi darah yang dimaksud dalam pasal ini, ditegaskan dalam Pasal 80 ayat (3), dipidana dengan pidana penjara paling lama 15 tahun dan denda paling banyak Rp. 300.000.000,- (tiga ratus juta rupiah).

Sedangkan bagi siapa pun yang tanpa keahlian dan kewenangan baik itu tenaga medis dan atau dokter, yang dengan sengaja melakukan

\footnotetext{
${ }^{7}$ UU No. 23 Tahun 1992 tentang Kesehatan
} 
transplantasi organ atau jaringan tubuh seperti yang dimaksud dalam Pasal 34 ayat (1), menurut ketentuan dalam Pasal 81 (1) a, dipidana dengan pidana penjara paling lama 7 tahun dan atau pidana denda paling banyak Rp. 140.000 .000 (seratus empat puluh juta rupiah). Pada Pasal 81 ayat (2) a menyebutkan bahwa barang siapa dengan sengaja mengambil organ dari seorang donor tanpa memperhatikan kesehatan donor dan atau tanpa persetujuan donor dan ahli waris atau keluarganya sebagaimana dimaksud dalam Pasal 34 ayat (2), dipidana dengan pidana penjara paling lama 7 (tujuh) tahun dan atau pidana denda paling banyak Rp 140.000.000,00 (seratus empat puluh juta rupiah).

Sejak tahun 1981 telah ada peraturan yang mengatur tentang transplantasi ini, yaitu melalui PP Nomor 18 Tahun 1981, Bab V mengatur tentang Transplantasi Alat dan atau Jaringan Tubuh Manusia, Bab VI tentang Pengambilan Alat dan atau Jaringan Tubuh Manusia Korban Kecelakaan, Bab VII tentang Donor, serta Bab VIII tentang Perbuatan yang Dilarang. Sesuai dengan Pasal 17 PP ini menegaskan salah satu perbuatan yang dilarang adalah memperjualbelikan alat dan atau jaringan tubuh manusia. ${ }^{8}$

\section{Transplantasi dan Donor Organ Tubuh Menurut Para Ulama}

Sebenarnya, kajian yang membahas tentang praktek transplantasi jaringan maupun organ dalam khazanah intelektual dan keilmuan fikih Islam klasik relatif jarang dan hampir tidak pernah dikupas oleh fukaha secara mendetail dan jelas yang mungkin karena faktor barunya masalah ini dan dimensi terkait yang komplek yang meliputi kasus transplantasi. Oleh karena itu tidak heran jika hasil ijtihad dan penjelasan tentang masalah ini banyak berasal dari pemikiran para ahli fikih kontemporer, keputusan lembaga dan institusi Islam serta simposium nasional maupun internasional.

${ }^{8}$ Lihat Undang-Undang RI No. 23 Tahun 1992 Tentang Kesehatan
Masalah transplantasi dalam kajian hukum Islam diuraikan menjadi dua bagian besar pembahasan yaitu: Pertama, penanaman jaringan/organ tubuh dari tubuh yang sama; Kedua, penanaman jaringan/organ dari individu lain, seperti manusia dalam bentuk; [a]. Penanaman jaringan/organ yang diambil dari individu orang hidup. [b]. Penanaman jaringan/organ yang diambil dari individu orang mati. Tetapi bisa juga diambil dari binatang dalam bentuk; [a]. Penanaman jaringan/organ yang diambil dari binatang tidak najis/halal. [b]. Penanaman jaringan/organ yang diambil dari binatang najis/haram.

Penanaman organ/jaringan yang diambil dari tubuh ke daerah lain pada tubuh tersebut. Seperti, praktek transplantasi kulit dari suatu bagian tubuh ke bagian lain dari tubuhnya yang terbakar atau dalam kasus transplantasi penyumbatan dan penyempitan pembuluh darah jantung dengan mengambil pembuluh darah pada bagian kaki. Masalah ini hukumnya adalah boleh berdasarkan analogi (qiyas) diperbolehkannya seseorang untuk memotong bagian tubuhnya yang membahayakan keselamatan jiwanya karena suatu sebab.

Penanaman jaringan/organ tunggal yang diambil dari individu lain yang masih hidup dan dapat mengakibatkan kematian donaturnya bila diambil. Seperti, jantung, hati dan otak. Maka hukumnya adalah tidak boleh. Atas dasar Firman Allah SW'T yang artinya "Dan belanjakanlah (barta bendamu) di jalan Allah, dan janganlah kamu menjatubkan dirimu sendiri ke dalam kebinasaan, dan berbuat baiklah, karena sesunggubnya Allah menyukai orang-orang yang berbuat baik. (Al-Baqarah: 195). Juga dalam FirmanNya "Dan janganlah kamu membunub dirimu sendiri, sesunggubnya Allah adalah Maba Penyayang kepadamu. (An-Nisa: 29) Serta "Dan tolong menolonglah kamu dalam kebaikan dan takwa, dan jangan tolong menolong dalam berbuat dosa dan pelanggaran. (Al-Maidah: 2).

Penanaman jaringan/organ yang diambil dari orang lain yang masih hidup yang tidak mengakibatkan kematiannya seperti, organ tubuh ganda diantaranya ginjal atau kulit atau dapat juga dikategorikan disini praktek donor darah. Pada dasarnya masalah ini diperbolehkan 
hanya harus memenuhi syarat-syarat berikut dalam prakteknya yaitu; [a]. Tidak akan membahayakan kelangsungan hidup yang wajar bagi donatur jaringan/organ. Karena kaidah hukum Islam menyatakan bahwa suatu bahaya tidak boleh dihilangkan dengan resiko mendatangkan bahaya serupa/sebanding; [b]. Hal itu harus dilakukan oleh donatur dengan sukarela tanpa paksaan dan tidak boleh diperjual belikan; [c]. Boleh dilakukan bila memang benar-benar transplantasi sebagai alternatif peluang satu-satunya bagi penyembuhan penyakit pasien dan benar-benar darurat; [d]. Boleh dilakukan bila kemungkinan keberhasilan transplantasi tersebut sangat besar. ${ }^{9}$

Namun demikian, ada pengecualian dari semua kasus tranplantasi yang diperbolehkan yaitu tidak dibolehkan tranplantasi buah zakar meskipun organ ini ganda karena beberapa alasan; [a]. Merusak citra dan penampilan lahir ciptaan manusia; [b]. Mengakibatkan terputusnya keturunan bagi donatur yang masih hidup; [c]. Dalam hal ini tranplantasi tidak dinilai darurat dan kebutuhannya tidak mendesak; [d]. Dapat mengacaukan garis keturunan. Sebab menurut ahli kedokteran, organ ini punya pengaruh dalam menitiskan sifat keturunan. ${ }^{10}$

Penanaman jaringan/organ tubuh diambil dari orang yang kondisinya benar-benar telah mati (kematian otak dan jantungnya sekaligus). Sesungguhnya telah banyak fatwa dan konsensus ulama dari berbagai muktamar, lembaga, organisasi dan institusi internasional yang membolehkan praktek transplantasi ini diantaranya; [a]. Konperensi OKI (di Malaysia, April 1969 M) dengan ketentuan kondisinya darurat dan tidak boleh diperjualbelikan; [b]. Lembaga Fikih Islam dari Liga Dunia Islam (dalam keputusan muzakarahnya di Mekkah, Januari 1985 M; [c]. Majelis Ulama Arab Saudi (dalam keputusannya no. 99 tgl. 6/11/1402H); [d]. Panitia Tetap Fawa Ulama dari negara-negara Islam

9 Lihat hasil mudzakarah lembaga fiqh Islam dari Liga Dunia Islam/Rabithah Alam Islami, edisi Januari 1985 M.

${ }^{10}$ Ensiklopedi Kedokteran Modern, Vol. III., hlm. 583 seperti; Kerajaan Yordania, Negara Kuwait (oleh Dirjen Fatwa Departemen Wakaf dan Urusan Islam keputusan no.97 tahun 1405 H); Mesir. (dengan keputusan Panitia Tetap fatwa Al-Azhar no. 491); Al-Jazair (Keputusan Panitia Tetap Fatwa Lembaga Tinggi Islam Aljazair, 20/4/1972 dengan ketentuan sebagai berikut : 1. Harus dengan persetujuan orang tua mayit/walinya atau wasiat mayit. 2 . Hanya bila dirasa benar-benar memerlukan dan darurat. 3. Bila tidak darurat dan keperluannya tidak urgen atau mendesak, maka harus memberikan imbalan pantas kepada ahli waris donatur tanpa transaksi dan kontrak jual-beli.

Disamping itu banyak fatwa dari kalangan ulama bertaraf Internasional yang membolehkan praktek tersebut antara lain: [a]. Abdurrahman bin Sa'di (1307-1367H.); [b]. Ibrahim Al-Ya'kubi (dalam bukunya Syifa Alqobarib); [c]. Jadal Haq (mufti Mesir dalam majalah AlAzhar vol. 7 edisi Romadhon 1403); [d]. DR. Yusuf Qordhowi (dalam Fatawa Mu'ashiroh II/530); [e]. DR. Rouf Syalabi (harian Syarh Ausath, edisi 3725, Rabu 8/2/1989); [f]. DR. Abd. Jalil Syalabi (harian Syarb Ausath edisi 3725, 8/2/1989M.); [g]. DR. Mahmud As-Sarthowi (dalam bukunya Zar'ul A'dho, Yordania); [h]. DR. Hasyim Jamil (majalah Risalah Islamiyah, edisi 212).

Secara umum dan pada prinsipnya mereka membolehkannya dengan alasan dan dalil sebagai berikut; [a]. Al-Qur'an surat AlBaqarah: 173; "Sesungguhnya Allah hanya mengharamkan bagimu bangkai, darah, daging babi dan binatang yang (ketika disembelih) disebut (nama) selain Allah. Tetapi barangsiapa dalam keadaan terpaksa (memakannya) sedang ia tidak menginginkannya dan tidak (pula) melampani batas, maka tidak ada dosa baginya. Sesunggubnya Allah Maha Pengampun lagi Maha Penyayang”. Surat al-Maidah: $32 ;$... dan barang siapa yang memelihara kebidupan seorang manusia, maka seolah-olah dia telah memelihara kehidupan manusia semuanya. Al-Baqarah:185; “... Allah menghendaki kemudahan bagimu dan tidak menginginkan kesempitan bagimu...; [b]. Hal itu sebagai amal jariyah bagi donatur yang telah mati dan sangat berguna bagi kemanusiaan; [c]. 
Kaedah-kaedah umum hukum Islam yang mengharuskan dihilangkannya segala bahaya (misalnya kaedah الضرر يز ال).

Sebenarnya hampir semua ulama mendukung praktek ini asalkan mengikuti ketentuan-ketentuan kaedah syari'ah kecuali sebagian kecil dari mereka yang keberatan dan tidak memperbolehkannya seperti; Syeikh As-Sya'rowi (harian Alliwa' edisi 226, 27/6/1407), Al-Ghomari (dalam bukunya tentang baramnya transplantasi), As-Sumbuli (Qodhoya fiqhiyyah mu'ashiroh), Hasan Assegaf (dalam bukunya tentang tranplantasi) dan DR. Abd. Salam As-Sakri (dalam bukunya tentang transplantasi) dan lainnya. Alasan mereka secara umum adalah keberatan mereka terhadap praktek transplantasi karena dapat berakibat dan menjurus kepada tindakan merubah dan merusak kehormatan jasad manusia yang telah dimuliakan Allah. semuanya itu sebenarnya dapat ditangkal dan diatasi atau ditanggulangi dengan mengikuti ketentuan-ketentuan medis dan syari'ah yang berlaku dengan penuh kehati-hatian dan amanah.

Selengkapnya argumentasi kelompok yang mengharamkan transplantasi adalah sebagai berikut. Hukum tranplanstasi organ dari seseorang yang telah mati berbeda dengan hukum transplantasi organ dari seseorang yang masih hidup. Untuk mendapatkan kejelasan hukum trasnplantasi organ dari donor yang sudah meninggal ini, terlebih dahulu harus diketahui hukum pemilikan tubuh mayat, hukum kehormatan mayat dan hukum keadaan darurat. Dengan asums bahwa diperlukan adanya penjelasan tentang hukum pemilikan terhadap tubuh manusia setelah dia mati. Merupakan suatu hal yang tidak diragukan lagi bahwa setelah kematiannya, manusia telah keluar dari kepemilikan serta kekuasaannya terhadap semua hal; baik harta, tubuh, maupun istrinya. Dengan demikian, dia tidak lagi memiliki hak terhadap tubuhnya. Maka ketika dia memberikan wasiat untuk mendonorkan sebagian anggota tubuhnya, berarti dia telah mengatur sesuatu yang bukan haknya. Jadi dia tidak lagi diperbolehkan untuk mendonorkan tubuhnya. Dengan sendirinya wasiatnya dalam hal itu juga tidak sah. Memang dibolehkan untuk memberikan sebagian hartanya, walaupunl harta tersebut akan keluar dari kepemilikannya ketika hidupnya berakhir. Tetapi itu disebabkan karena syara' memberikan izin pada manusia tentang perkara tersebut. Dan itu merupakan izin khusus pada harta, tentu tidak dapat diberlakukan terhadap yang lain. Dengan demikian manusia tidak diperbolehkan memberikan wasiat dengan mendonorkan sebagian anggota tubuhnya setelah dia mati.

Adapun bagi ahli waris; sesungguhnya syara' mewariskan pada mereka harta yang diwariskan. Namun syara' tidak mewariskan jasadnya kepada mereka, sehingga mereka tidak berhak untuk mendonorkan apapun dari si mati. Kalau terhadap ahli waris saja demikian, apalagi dokter atau penguasa, mereka sama sekali tidak berhak untuk mentransplantasikan organ orang setelah mati pada orang lain yang membutuhkan.

Terlebih lagi terdapat keharusan untuk menjaga kehormatan si mati serta adanya larangan untuk menyakitinya sebagaimana larangan pada orang yang hidup. Rasulullah saw bersabda ${ }^{11}$ :

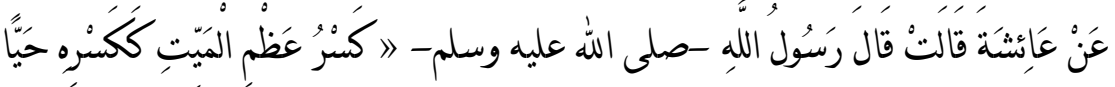

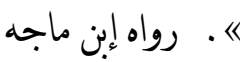

"Mematabkan tulang orang yang telah mati sama bukumnya dengan memotong tulangnya ketika ia masib hidup".

Dengan demikian Rasulullah saw melarang untuk merampas dan menyakiti (si mati). Memang benar bahwa melampaui batas terhadap orang mati dengan melukai atau memotong atau bahkan memecahkan (tulang) tidak ada jaminan (diyat) sebagaimana ketika dia masih hidup. Akan tetapi jelas bahwa melampaui batas terhadap jasad si mati atau menyakitinya dengan cara mengambil anggota tubuhnya adalah haram;

1111 Ibn Majah, Sunan Ibn Majah, hadis nomor 1684, bab Larangan Memecabkan Tulang Mayat, juz V hlm. 182 
dan haramnya bersifat pasti (qath'). Mengenai keadaan darurat yang telah dijadikan alasan oleh aparat negara, jajaran humas serta muftinya yang membolehkan transplantasi, hal tersebut membutuhkan kajian tentang keadaan darurat serta penerapannya pada masalah transplantasi organ.

Sesungguhnya Allah SWT telah membolehkan orang dalam keadaan darurat hingga kehabisan bekal dan hidupnya terancam kematian untuk makan apa saja yang dijumpainya. Meski makanan tersebut diharamkan oleh Allah, namun dalam kondisi darurat boleh dimakan sekedar untuk memulihkan tenaganya serta agar tetap hidup. Maka illat bolehnya makan makanan haram adalah untuk menjaga kehidupan manusia. Dengan mengkaji anggota tubuh yang akan ditransplantasikan, maupun maksud transplantasi maka adakalanya penyelamatan hidup manusia tergantung pada tranplantasi (tentu berdasarkan dugaan kuat) seperti jantung, hati maupun kedua ginjal. Atau ada kalanya tranplantasi anggota tubuh yang tidak berhubungan langsung dengan penyelamatan hidup. Misalnya tranplantasi kornea, atau pupil atau mata secara keseluruhan dari orang yang telah mati.

Adapun anggota tubuh yang diduga kuat dapat menyelamatkan kehidupan manusia maka illat-nya dalam hal ini tidak sempurna. Karena kadang-kadang berhasil, kadang-kadang juga tidak. Hal ini berbeda dengan illat memakan bangkai; yang secara pasti mampu menyelamatkan hidup manusia. Terlebih lagi bahwa sebagian dari illah cabang ('illat al-far'u) dalam hal ini transplantasi, adalah terbebas dari pertentangan dalil yang lebih kuat, yang mengharuskan kebalikan dari perkara yang telah ditetapkan oleh 'illat qiyas. 'Illat qiyas dalam transplantasi organ adalah untuk memelihara kehidupan manusia, sebagaimana pada kasus makan bangkai. Padahal illat tersebut masih berupa 'diduga kuat'. Ini bertentangan dengan (dalil) yang lebih kuat yaitu kehormatan jenazah serta larangan menyakiti atau merusaknya. Berdasarkan hal ini tidak diperbolehkan melakukan transplantasi organ; yang dengan transplantasi tersebut kehidupan seseorang tergantung padanya.
Sedangkan transplantasi organ yang penyelamatan kehidupan orang tidak tergantung padanya; atau dengan kata lain kegagalan transplantasi tersebut tidak mengakibatkan kematian, maka illat yang ada pada pokok ('illah al-ashl) yaitu pemeliharaan terhadap kehidupan manusia menjadi tidak ada. Dengan begitu hukum darurat tidak berlaku disini. Maka tidak diperbolehkan melakukan tranplantasi organ dari seseorang yang telah mati; sementara dia terpelihara darahnya baik muslim, kafir drimmi, mu'abid maupun musta'min pada orang lain yang kehidupannya tergantung pada (keberhasilan) tranplantasi organ tersebut. ${ }^{12}$

Penanaman jaringan/organ yang diambil dari tubuh binatang yang bukan najis, seperti binatang ternak (sapi, kerbau, kambing). Dalam hal ini tidak ada larangan bahkan diperbolehkan dan termasuk dalam kategori obat yang mana kita diperintahkan Nabi untuk mencarinya bagi yang sakit. Jika Binatang tersebut najis/haram seperti, babi atau bangkai binatang dikarenakan mati tanpa disembelih secara islami terlebih dahulu. Dalam hal ini tidak dibolehkan kecuali dalam kondisi darurat dan tidak ada pilihan lain. ${ }^{13}$

\section{Analisa}

Transplantasi organ tubuh sebagai salah satu metode dan solusi pengobatan modern merupakan masalah ijtihadiyah, sehingga menjadi lapangan ijtihad. Karena masalahnya masalah ijtihadiyah berarti peluang untuk terjadi perbedaan pendapat sangat terbuka lebar, sejauhmana seorang mujtahid melihat persoalan tersebut dan "menggodoknya" dalam kerangka metodologi instinbat. Dari segi hukum Islam, apakah transplantasi dan donor organ tubuh diperbolehkan atau tidak dijawab dengan merujuk pada sumber

12 http://banumushtafa.multiply.com/journal/item/6. Lihat juga http://fosmik-unhas.tripod.com/ buletin.html. Lihat pula http://makmumanshory.blogspot.com/2009/05/ bukum-transplantasi-organ-tubuh.

${ }^{13}$ www. Transpalantasi. Corn diakses pada 20 Mei 2010 
tekstual utama (Qur'an dan hadis) maupun kitab-kitab fikih, ushul fiqh dan kaidah-kaidah figh.

Dari segi metodologi, untuk menjawab masalah-masalah kontemporer ulama mencari kasus-kasus yang dibahas dalam kitabkitab lama itu, atau kasus-kasus yang analog dengannya. Pengambilan keputusan seperti ini dibimbing oleh seperangkat prinsip umum, yang disebut usul fikih. Di antaranya, ada prinsip pertimbangan manfaat dan mudarat dari suatu keputusan; prinsip mendahulukan menghindari keburukan; prinsip bahwa manfaat yang amat besar dapat mengatasi keburukan-keburukan inheren yang lebih kecil; prinsip darurat; prinsip maslahah atau kesejahteraan publik; dan sebagainya.

Dalam hal transplantasi dan donor organ tubuh, keputusankeputusan legal-etis bisa dicari dengan melihat bagaimana kitab-kitab klasik itu memandang penggunaan bagian-bagian tubuh manusia untuk tujuan penyembuhan. ${ }^{14}$ Kadang-kadang, upaya ini dilakukan dengan tak memperhatikan konteksnya dengan baik, tapi hanya melihat kasus dimana organ tubuh manusia diperlakukan meski dalam konteks yang amat jauh berbeda dengan konteks pencangkokan. Meskipun pendekatan historis semacam ini telah sering dikritik, tapi masih juga kerap digunakan.

Sebagaimana halnya dalam kasus-kasus lain, karena karakter fikih dalam Islam, pendapat yang muncul tak hanya satu, tapi beragam, dan satu dengan lainnya bahkan terkadang sering bertolak belakang, meski menggunakan sumber-sumber yang identik. Di sini akan disampalkan kesimpulan beberapa pandangan yang cukup populer mengenai isu

14 Pada bagian ini, kecuali jika disebutkan lain, sumber utafna yang digunakan adalah salah satu literatur paling komprehensif dalam masalah ini, karya Abu Fadl Mohsen Ibrahim, Organ Transplantation, Euthanasia, Clonning and Animal Experimentation: An Islamic View, The Islamic Foundation, Leicester, 2001 (diterjemahkan menjadi Kloning, Eutanasia, Transfuse Darah, Transplantasi Organ, dan Eksperimen pada Hewan, Telaah Fikih dan Bioetika Islam, Serambi 2004.) ini. ${ }^{15}$ Pandangan yang menentang transplantasi dan donor organ tubuh diajukan atas dasar setidaknya tiga alasan; [a]. Kesucian hidup/tubuh manusia. Setiap bentuk agresi terhadap tubuh manusia dilarang, karena ada beberapa perintah yang jelas mengenal ini dalam Al-Qur'an. Dalam kaitan ini ada satu hadis Nabi Muhammad yang terkenal yang sering dikutip untuk menunjukkan dilarangnya manipulasi atas tubuh manusia, meskipun sudah menjadi mayat: "Mematabkan tulang mayat seseorang adalah sama berdosa dan melanggarnya dengan mematabkan tulang orang itu ketika ia masib hidup". [b]. Tubuh manusia adalah amanah. Hidup, diri, dan tubuh manusia pada dasarnya bukan miliknya sendiri, tapi pinjaman dari Tuhan dengan syarat untuk dijaga, karena itu manusia tak memiliki hak mendonorkannya pada orang lain. [c]. Tubuh tak boleh diperlakukan sebagai benda material semata. Pencangkokan dilakukan dengan memotong organ tubuh seseorang untuk dicangkokkan pada tubuh orang lain; di sini tubuh dianggap sebagai benda material semata yang bagian-bagiannya bisa dipindahpindah tanpa mengurangi ke-tubuh-an seseorang.

Sedangkan pandangan yang mendukung pencangkokan organ memiliki beberapa dasar berikut; [a]. Kesejahteraan publik (maslahah). Pada dasarnya manipulasi organ memang tak diperkenankan, meski demikian ada beberapa pertimbangan lain yang bisa mengalahkan larangan itu, yaitu potensinya untuk menyelamatkan hidup manusia, yang mendapat bobot amat tinggi dalam hukum Islam. Dengan alasan ini pun, ada beberapa kualifikasi yang mesti diperhatikan: 1). Pencangkokan organ boleh dilakukan jika tak ada alternatif lain untuk menyelamatkan nyawa; derajat keberhasilannya cukup tinggi; 2). Ada persetujuan dari pemilik organ asli (atau ahli warisnya); 3). Penerima organ sudah tahu persis segala implikasi pencangkokan (informed consent). [b]. Altruisme, ada kewajiban yang amat kuat bagi seorang

15 Akan amat menarik mencermati bagaimana Muslim Indonesia-melalui lembaga-lembaga pemberi fatwa seperti MUI, Majelis Tarjih Muhammadiyah, atau Babtsul Masa'il NU, merespon persoalan ini; namun ini tak bisa dilakukan dalam tulisan ini. 
Muslim untuk membantu manusia lain, khususnya sesama Muslim; pendonoran organ secara sukarela merupakan bentuk altruisme yang amat tinggi, dalam arti si donor tak menerima uang untuk tindakannya, dan karenanya dianjurkan. Untuk ini pun dengan beberapa syarat; 1). Ada persetujuan dari donor; 2). Nyawa donor tak terancam dengan pengambilan organ dari tubuhnya; 3). Pencangkokan yang akan dilakukan berpeluang berhasil amat tinggi.

Setelah beberapa alasan yang membolehkan itu, pendukung pencangkokan organ masih menambahkan beberapa syarat lain; [a] Organ tak diperoleh melalui transaksi jual-beli, karena tidak sah hukumnya menjual organ; [b]. Seorang muslim, kecuali dalam situasisituasi yang mendesak, hanya boleh menerima organ dari muslim lainnya. Ada satu implikasi yang menarik dari sini. jika syarat ini dikombinasikan dengan kebolehan (dan dalam kasus tertentu kewajiban) melakukan pencangkokan organ, maka mendonorkan organ bagi muslim hukumnya adalah wajib sosial (fardh kifayah), yaitu dalam suatu komunitas muslim, adalah kewajiban bagi salah seorang muslim untuk mendonorkan organnya jika ada orang lain yang membutuhkan.

Memperhatikan perbincangan di atas, penulis mencoba melakukan penalaran dengan pendekatan ushul fiqh. Perbedaan pandangan ulama terhadap hukum transplantasi dan donor organ tubuh berawal dari perbedaan pandangan mereka tentang status kepemilikan tubuh. Pada hakikatnya, semua yang wujud termasuk tubuh adalah milik Allah secara mutlak. Kita hanya diberi hak untuk memanfaatkanya (baqq al-manfa'ah). Sisi lain yang yang menjadi pemicu perbedaan tersebut adalah persoalan kehormatan dan kemuliaan manusia, serta kondisi atau keadaan yang "memaksa" (dharurat).

Menurut hemat penulis, syara' membolehkan seseorang pada saat hidupnya dengan sukarela tanpa ada paksaan siapa pun untuk menyumbangkan sebuah organ tubuhnya atau lebih kepada orang lain yang membutuhkan organ yang disumbangkan itu, seperti tangan atau ginjal. Ketentuan itu dikarenakan adanya hak bagi seseorang yang tangannya terpotong, atau tercongkel matanya akibat perbuatan orang lain untuk mengambil diyat (tebusan), atau memaafkan orang lain yang telah memotong tangannya atau mencongkel matanya. Memaafkan pemotongan tangan atau pencongkelan mata, hakekatnya adalah tindakan menyumbangkan divat. Penyumbangan diyat itu berarti menetapkan adanya pemilikan diyat. Melalui penalaran analogis $\left(t a^{\prime} l i l i\right)$ berarti pula menetapkan adanya pemilikan organ tubuh yang akan disumbangkan dengan diyatnya itu. Adanya hak milik orang tersebut terhadap organ tubuhnya berarti telah memberinya hak untuk memanfaatkan organ-organ tersebut, yang berarti ada kemubahan menyumbangkan organ tubuhnya kepada orang lain yang membutuhkan. Kebolehan memberikan maaf dalam masalah qishash dan membayar diyat Allah SWT berfirman: "Maka barangsiapa yang mendapat suatu pemaafan dari saudaranya, hendaklah (yang memaafkan) mengikuti dengan cara yang baik, dan hendaklah (yang diberi maaf) membayar (diyat) kepada yang memberi maaf dengan cara yang baik (pula). Yang demikian itu adalah suatu keringanan dari Tuban kalian dan suatu ralmat. (AlBaqarah: 178).

Kebolehan memberi maaf pada kasus qishash dan menggantinya dengan diyat jelas menunjukkan bahwa manusia memiliki hak terhadap tubuhnya bahkan ahli warisnyapun memiliki hak terhadap tubuh saudaranya. Syarat bagi kemubahan menyumbangkan organ tubuh pada saat seseorang masih hidup, ialah bukan merupakan organ vital yang menentukan kelangsungan hidup pihak penyumbang, seperti jantung, hati, dan kedua paru-paru. Hal ini dikarenakan penyumbangan organ-organ tersebut akan mengakibatkan kematian pihak penyumbang, yang berarti dia telah membunuh dirinya sendiri. Padahal seseorang tidak dibolehkan membunuh dirinya sendiri atau meminta dengan sukarela kepada orang lain untuk membunuh dirinya. Sebagaimana dalam firman Allah SWT: "Dan janganlah kalian membunuh diri-diri kalian sungguh Allab Maha Penyayang kepadamu".(An-Nisaa': 29) Juga firman Allah SWT: "...dan janganlab kalian membunuh jiwa yang 
diharamkan Allab (membunubnya) melainkan dengan sesuatu (sebab) yang benar'. (Al-An'aam : 151)

Keharaman membunuh orang yang diharamkan Allah (untuk membunuhnya) ini mencakup membunuh orang lain dan membunuh diri sendiri. Imam Muslim meriwayatkan bahwa Rasulullah SAW bersabda 16 :

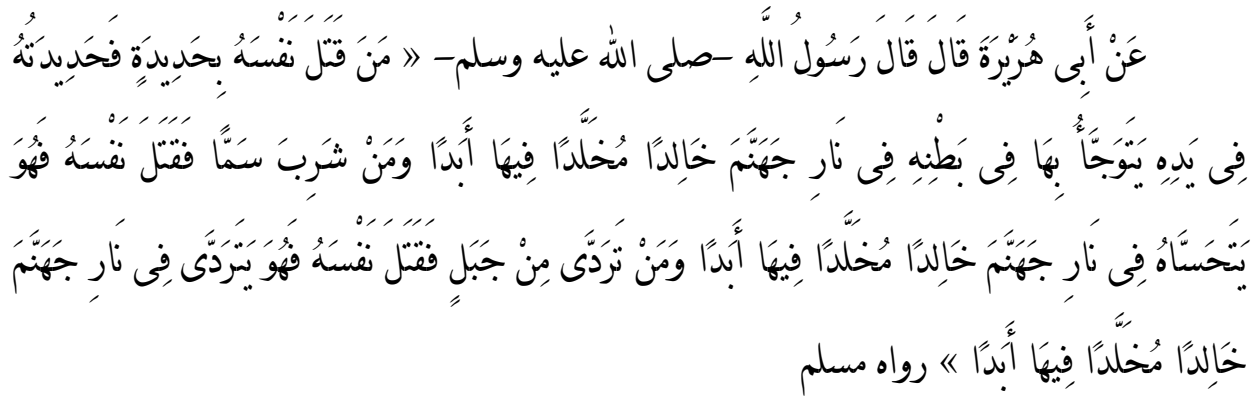

Dari Abu Hurairoh, bersabda Rasulullah $S A W$ : "...Siapa saja yang membunuh dirinya sendiri dengan besi, maka besi ditangannya itu akan dia tusuk-tusukekan keperutnya dalam neraka Jahannam, dia kekal selama-lamanya di dalamnya, dan siapa yang meminum racun yang membuat dirinya terbunuh maka ia akan meminum racun itu dalam neraka Jahannam dan kekeal di dalamnya selama-lamanya, dan siapa saja yang menjatubkean diri dari sebuah gunung dan membunub dirinya sendiri, maka dia akan dimasukkan ke dalam neraka Jahannam, kekal di dalamnya selama-lamanya.

Demikian pula seorang laki-laki tidak dibolehkan menyumbangkan dua testis (zahaf), meskipun hal ini tidak akan menyebabkan kematiannya, sebab Rasulullah SAW telah melarang pengebirian/pemotongan testis (al khisha), yang akan menyebabkan kemandulan. Imam Bukhari meriwayatkan dari Abdullah bin Mas'ud RA, dia berkata ${ }^{17}$ : 737

${ }^{16}$ Imam Muslim, Shahih Muslim, Bab Keharaman Membunub Diri, Juz I., hlm.

${ }^{17}$ Imam al-Bukhari, Shahih al-Bukhari, Hadis nomor 4339, Juz IV, hlm. 1687.

$$
\text { عنّ عبد الله رضي الله عنه قال : كنا نغزو مع النبي صلى الله عليه و سلم وليس معنا ساء فقلنا ألا }
$$

"Kami dabulu pernab berperang bersama Nabi SAW sementara isteri kami tidak ada bersama kami. Kami berkata, 'Wabai Rasulullah bolehkah kami melakukan pengebirian? Maka beliau melarang kami untuk melakukannya"

Hukum ini dapat diterapkan juga untuk penyumbangan satu buah testis, kendatipun hal ini tidak akan membuat penyumbangnya menjadi mandul. Ini karena sel-sel kelamin yang terdapat dalam organorgan reproduktif -yaitu testis pada laki-laki dan indung telur pada perempuan merupakan substansi yang dapat menghasilkan anak, sebab kelahiran manusia memang berasal dari sel-sel kelamin. Dalam testis terdapat sel-sel penghasil sel-sel sperma mengingat testis merupakan pabrik penghasil sel sperma. Dan testis akan tetap menjadi tempat penyimpanan -yakni pabrik penghasil sel sperma dari selselnya- baik testis itu tetap pada pemiliknya atau pada orang yang menerima transplantasi testis dari orang lain. Atas dasar itu, maka kromosom anak-anak dari penerima transplantasi testis, sebenarnya berasal dari orang penyumbang testis, sebab testis yang telah dia sumbangkan itulah yang telah menghasilkan sel-sel sperma yang akhirnya menjadi anak. Karena itu, anak-anak yang dilahirkan akan mewarisi sifat-sifat dari penyumbang testis dan tidak mewaris sedikitpun sifat-sifat penerima sumbangan testis. Jadi pihak penyumbang testislah yang secara biologis menjadi bapak mereka. Maka dari itu, tidak dibolehkan menyumbangkan satu buah testis, sebagaimana tidak dibolehkan pula menyumbangkan dua buah testis. Sebab, menyumbangkan dua buah testis akan menyebabkan kemandulan pihak penyumbang. Di samping itu, menyumbangkan satu atau dua buah testis akan menimbulkan pencampuradukan dan penghilangan nasab. Padahal Islam telah mengharamkan hal ini dan sebaliknya telah memerintahkan pemeliharaan nasab. Imam Ibnu 
Majah meriwayatkan dari Ibnu Abbas RA, dia mengatakan bahwa Rasulullah SAW bersabda ${ }^{18}$ :

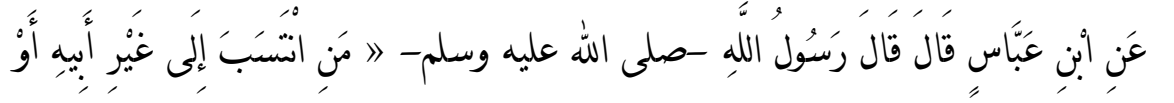

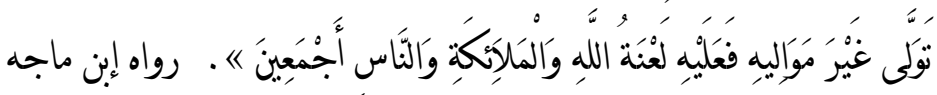

"Siapa saja yang menghubungkan nasab kepada orang yang bukan ayahnya, atau (seorang budak) bertuan kepada selain tuannya, maka dia akan mendapat laknat dari Allah, para malalkat, dan seluruh manusia."

Demikian pula sabda Rasulullah dalam hadis lain ${ }^{19}$ :

$$
\begin{aligned}
& \text { عن أبي ذر رضي الله عنه : أنه سمع النبي صلى الله عليه و سلم يقول ( ليس من رجل } \\
& \text { ادعى لغير أبيه - وهو بعلمه - إلا كر ومن ادعى قوما ليس له فيهم نسب فلينبواً معقده من }
\end{aligned}
$$

Tiadalah seorang laki-laki yang mengaku-ngaku (sebagai anak) kepada orang yang bukan bapaknya, padahal dia tahu bahwa orang itu bukan bapaknya, maka kafirlah ia dan siapa saja yang mengaku-ngaku bernasab kepada suatu kaum padahal tidak ada hubungan nasabnya maka sediakanlah tempatnya dineraka."

Demikian pula Islam telah melarang seorang wanita memasukkan ke dalam kaumnya nasab yang bukan dari kaumnya, dan melarang seorang laki-laki mengingkari anaknya sendiri. Imam AlDarimi meriwayatkan dari Abu Hurairah RA bahwa dia mendengar Rasulullah SAW bersabda tatkala turun ayat $l i^{\prime} a n^{20}$ :

${ }^{18}$ Ibn Majah, Sunan Ibn Majah, Hadis No. 2707, Juz VIII, hlm. 146 19 Ibid, Hadis No. 3317, Juz III, hlm. 1292

20 Abu Daud, Sunan Abu Daud, hadis nomor 2265, juz VII, hlm. 17

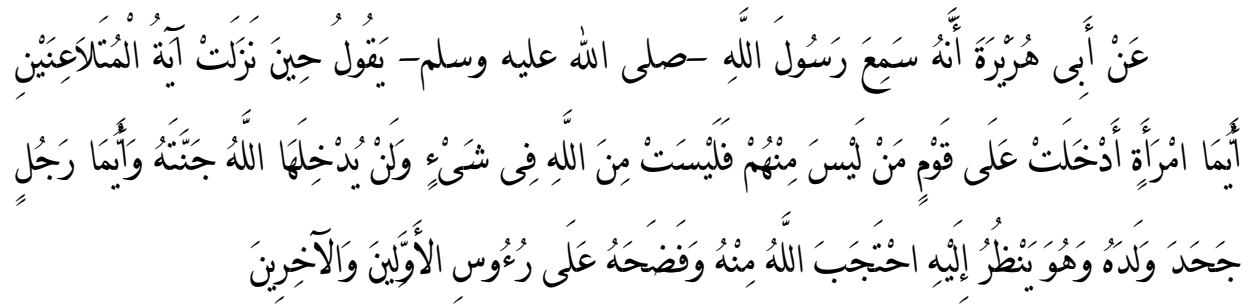

"Siapa saja perempuan yang memasukean kepada suatu kaum nasab (seseorang) yang bukan dari kalangan kaum itu, maka dia tidak akan mendapat apa pun dari Allab dan Allah tidak akan pernah memasukkannya ke dalam surga. Dan siapa saja laki-laki yang mengingkari anaknya sendiri padahal dia melihat (kemiripan)nya, maka Allah akan tertutup darinya dan Allah akan membeberkan perbuatannya itu di hadapan orang-orang yang terdabulu dan kemudian (pada Hari Kiamat nanti)."

Mengenai hukum pemilikan tubuh seseorang yang telah meninggal, menurut sebagian ulama yang menolak transplantasi dan donor organ tubuh, bahwa pada dasarnya tubuh orang tersebut tidak lagi dimiliki oleh seorang pun. Sebab dengan sekedar meninggalnya seseorang, sebenarnya dia tidak lagi memiliki atau berkuasa terhadap sesuatu apapun, entah itu hartanya, tubuhnya, ataupun isterinya. Oleh karena itu dia tidak lagi berhak memanfaatkan tubuhnya, sehingga dia tidak berhak pula untuk menyumbangkan salah satu organ tubuhnya atau mewasiatkan penyumbangan organ tubuhnya. Berdasarkan hal ini, maka seseorang yang sudah mati tidak dibolehkan menyumbangkan organ tubuhnya dan tidak dibenarkan pula berwasiat untuk menyumbangkannya. Sedangkan mengenai kemubahan mewasiatkan sebagian hartanya, kendatipun harta bendanya sudah di luar kepemilikannya sejak dia meninggal, hal ini karena Asy-Syari' (Allah) telah mengizinkan seseorang untuk mewasiatkan sebagian hartanya hingga sepertiga tanpa seizin ahli warisnya. Jika lebih dari sepertiga, harus seizin ahli warisnya. Adanya izin dari ahli waris hanya khusus untuk masalah harta benda dan tidak mencakup hal-hal lain. Izin ini tidak mencakup pewasiatan tubuhnya. Karena itu, dari sisi ini, 
dia tidak berhak berwasiat untuk menyumbangkan salah satu organ tubuhnya setelah kematiannya. Mengenai hak ahli waris, maka Allah SWT telah mewariskan kepada mereka harta benda si mayit, bukan tubuhnya. Dengan demikian, para ahli waris tidak berhak menyumbangkan salah satu organ tubuh si mayit, karena mereka tidak memiliki tubuh si mayit, sebagaimana mereka juga tidak berhak memanfaatkan tubuh si mayit tersebut. Padahal syarat sah menyumbangkan sesuatu benda, adalah bahwa pihak penyumbang berstatus sebagai pemilik dari benda yang akan disumbangkan, dan bahwa dia mempunyai hak untuk memanfaatkan benda tersebut. Dan selama hak mewarisi tubuh si mayit tidak dimiliki oleh para ahli waris, maka hak pemanfaatan tubuh si mayit lebih-lebih lagi tidak dimiliki oleh selain ahli waris, bagaimanapun juga posisi atau status mereka. Karena itu, seorang dokter atau seorang penguasa tidak berhak memanfaatkan salah satu organ tubuh seseorang yang sudah meninggal untuk ditransplantasikan kepada orang lain yang membutuhkannya.

Sepintas lalu, apa yang dikemukakan oleh sebagian ulama yang menolak transplantasi organ tubuh di atas dapat dibenarkan. Namun bila kita kembali merujuk pada kebolehan ahli waris memaafkan kesalahan pelaku qishah, menunjukkan bahwa ahli waris memiliki otoritas dan kewenangan terhadap tubuh saudaranya yang telah meninggal dunia. Dengan penalaran ta'lili, ahli waris dapat menyumbangkan atau memberikan organ tubuh tertentu dari saudaranya yang meninggal dunia kepada orang yang sangat memerlukannya.

Penolakan terhadap transplantasi dan donor organ tubuh juga beralasan pada masalah kemuliaan dan kehormatan mayat. Dari sisi kehormatan mayat dan penganiayaan terhadapnya, maka Allah SWT telah menetapkan bahwa mayat mempunyai kehormatan yang wajib dipelihara sebagaimana kehormatan orang hidup. Dan Allah telah mengharamkan pelanggaran terhadap kehormatan mayat sebagaimana pelanggaran terhadap kehormatan orang hidup. Allah menetapkan pula bahwa menganiaya mayat sama saja dosanya dengan menganiaya orang hidup. Diriwayatkan dari Aisyah Ummul Mu'minin RA bahwa Rasulullah SAW bersabda :

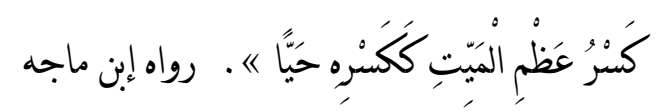

"Memecabkan tulang mayat itu sama dengan memecabkan tulang orang bidup". (HR. Ibn Majah).

Hadis di atas secara jelas menunjukkan bahwa mayat mempunyai kehormatan sebagaimana orang hidup. Begitu pula melanggar kehormatan dan menganiaya mayat adalah sama dengan melanggar kehormatan dan menganiaya orang hidup. Dan sebagaimana tidak boleh menganiaya orang hidup dengan membedah perutnya, atau memenggal lehernya, atau mencongkel matanya, atau memecahkan tulangnya, maka begitu pula segala penganiayaan tersebut tidak boleh dilakukan terhadap mayat. Sebagaimana haram menyakiti orang hidup dengan mencaci maki, memukul, atau melukainya, maka demikian pula segala perbuatan ini haram dilakukan terhadap mayat. Hanya saja penganiayaan terhadap mayat dengan memecahkan tulangnya, memenggal lehernya, atau melukainya, tidak ada denda (dlamaan) padanya sebagaimana denda pada penganiayaan orang hidup. Sebab Rasulullah SAW tidak menetapkan adanya denda sedikit pun terhadap seseorang yang telah memecahkan tulang mayat di hadapan beliau, ketika orang itu sedang menggali kubur. Rasulullah SAW hanya memerintahkan orang itu untuk memasukkan potongan-potongan tulang yang ada ke dalam tanah. Dan Rasulullah menjelaskan kepadanya bahwa memecahkan tulang mayat itu sama dengan memecahkan tulang hidup dari segi dosanya saja. Tindakan mencongkel mata mayat, membedah perutnya untuk diambil jantungnya, atau ginjalnya, atau hatinya, atau paru-parunya, untuk ditransplantasikan kepada orang lain yang membutuhkannya, dapat dianggap sebagai mencincang mayat. Padahal Islam telah melarang perbuatan ini. 
Dengan penjelasan fakta hukum mengenai pelanggaran kehormatan mayat dan penganiayaan terhadapnya ini, maka jelaslah bahwa tidak dibolehkan membedah perut mayat dan mengambi sebuah organnya untuk ditransplantasikan kepada orang lain. Ini karena tindakan tersebut dianggap sebagai pelanggaran terhadap kehormatan mayat serta merupakan penganiayaan dan pencincangan terhadapnya. Padahal melanggar kehormatan mayat dan mencincangnya telah diharamkan secara pasti oleh syara'. Alasan penolakan transplantasi dari sisi perusakan dan penganiayaan terhadap mayit dapat dibenarkan. Namun demikian, perlu difahami bahwa konteks hadis tersebut adalah peristiwa dimana seorang penggali kubur yang kasar mernatahkan tulang mayat karena kuburan yang sudah digali ternyata terlalu sempit. Ini jelas perbuatan yang tak menghormati mayat. Sementara dalam pencangkokan organ, ada tujuan yang jelas, dan tujuan itu amat mulia. Demikian pula, mengambil organ dengan alasan mulia yang jelas bukanlah tindakan yang melanggar amanah, tapi justru upaya memenuhi perintah lain Tuhan untuk menyelamatkan hidup sesama manusia apalagi dalam keadaan dharurat.

Keadaan darurat adalah keadaan di mana Allah membolehkan seseorang yang terpaksa yang kehabisan bekal makanan, dan kehidupannya terancam kematian untuk memakan apa saja yang didapatinya dari makanan yang diharamkan Allah, seperti bangkai, darah, daging babi, dan lain-lain. Apakah dalam keadaan seperti ini dibolehkan mentransplantasikan salah satu organ tubuh mayat untuk menyelamatkan kehidupan orang lain, yang kelangsungan hidupnya tergantung pada organ yang akan dipindahkan kepadanya? Untuk menjawab pertanyaan itu harus diketahui terlebih dahulu hukum darurat, sebagai langkah awal untuk dapat mengetahui hukum transplantasi organ tubuh dari orang yang sudah mati kepada orang lain yang membutuhkannya. Mengenal hukum darurat, maka Allah SWT telah membolehkan orang yang terpaksa yang telah kehabisan bekal makanan, dan kehidupannya terancam kematian untuk memakan apa saja yang didapatinya dari makanan yang diharamkan Allah seperti bangkai, darah, daging babi, dan lain-lain hingga dia dapat mempertahankan hidupnya. Allah SWT berfirman: "Sesungguhnya Allah hanya mengharamkan bagi kalian bangkai, darah, daging babi, dan binatang yang (ketika disembelih) disebut (Nama) selain Allah. Tetapi barangsiapa dalam keadaaan terpaksa (memakannya) sedang dia tidak menginginkannya dan tidak (pula) melampaui batas, maka tidak ada dosa atasnya”. (Al-Baqarah: 173)

Maka orang yang terpaksa tersebut boleh memakan makanan haram apa saja yang didapatinya, sehingga dia dapat memenuhi kebutuhannya dan mempertahankan hidupnya. Kalau dia tidak mau memakan makanan tersebut lalu mati, berarti dia telah berdosa dan membunuh dirinya sendiri. Padahal Allah SWT berfirman: "Dan janganlah kalian membunuh diri-diri kalian." (An-Nisaa' : 29)

Dari penjelasan di atas, dapatkah hukum darurat tersebut diterapkan dengan jalan Qiyas pada fakta transplantasi organ dari orang yang sudah mati kepada orang lain yang membutuhkannya guns menyelamatkan kehidupannya? Jawabannya memerlukan pertimbangan, sebab syarat penerapan hukum Qiyas dalam masalah ini ialah bahwa 'illat (sebab penetapan hukum) yang ada pada masalah cabang sebagai sasaran Qiyas, yaitu transplantasi organ, harus juga sama-sama terdapat pada masalah pokok yang menjadi sumber Qiyas yaitu keadaan darurat bagi orang yang kehabisan bekal makanan baik pada 'illat yang sama, maupun pada jenis 'illatnya. Hal ini karena Qiyas sesungguhnya adalah menerapkan hukum masalah pokok pada masalah cabang, dengan perantaraan 'illat pada masalah pokok. Maka jika 'illat masalah cabang tidak sama-sama terdapat pada masalah pokok, dalam sifat keumumannya atau kekhususannya, maka berarti 'illat masalah pokok tidak terdapat pada masalah cabang. Ini berarti hukum masalah pokok tidak dapat diterapkan pada masalah cabang. Dalam kaitannya dengan masalah transplantasi, organ yang ditransplantasikan dapat merupakan organ vital yang diduga kuat akan dapat menyelamatkan kehidupan, seperti jantung, hati, dua ginjal, dan 
dua paru-paru. Dapat pula organ tersebut bukan organ vital yang dibutuhkan untuk menyelamatkan kehidupan, seperti dua mata, ginjal kedua (untuk dipindahkan kepada orang yang masih punya satu ginjal yang sehat), tangan, kaki, dan yang semisalnya. Mengenal organ yang tidak menjadi tumpuan harapan penyelamatan kehidupan dan ketiadaannya tidak akan membawa kematian, berarti "illat masalah pokok yaitu menyelamatkan kehidupan tidak terwujud pada masalah cabang (transplantasi). Dengan demikian, hukum darurat tidak dapat diterapkan pada fakta transplantasi. Atas dasar itu, maka menurut syara' tidak dibolehkan mentransplantasikan mata, satu ginjal (untuk dipindahkan kepada orang yang masih mempunyai satu ginjal yang sehat), tangan, atau kaki, dari orang yang sudah meninggal kepada orang lain yang membutuhkannya. Sedangkan organ yang diduga kuat menjadi tumpuan harapan penyelamatan kehidupan, maka ada dua hal yang harus diperhatikan: Pertama, Illat yang terdapat pada masalah cabang (transplantasi) yaitu menyelamatkan dan mempertahankan kehidupan tidak selalu dapat dipastikan keberadaannya, berbeda halnya dengan keadaan darurat. Sebab, tindakan orang yang terpaksa untuk memakan makanan yang diharamkan Allah SWT, secara pasti akan menyelamatkan kehidupannya. Sedangkan pada transplantasi jantung, hati, dua paru-paru, atau dua ginjal, tidak secara pasti akan menyelamatkan kehidupan orang penerima organ. Kadang-kadang jiwanya dapat diselamatkan dan kadang-kadang tidak. Ini dapat dibuktikan dengan banyak fakta yang terjadi pada orang-orang yang telah menerima transplantasi organ. Karena itu, 'illat pada masalah cabang (transplantasi) tidak terwujud dengan sempurna. Kedua, Ada syarat lain dalam syarat-syarat masalah cabang dalam Qiyas, yaitu pada masalah cabang tidak dibenarkan ada nash lebih kuat yang bertentangan dengannya (ta'arudl raajib), yang berlawanan dengan apa yang dikehendaki oleh 'illat Qiyas. Dalam hal ini pada masalah cabang -yakni transplantasi organ- telah terdapat nash yang lebih kuat yang berlawanan dengan apa yang dikehendaki 'illat Qiyas, yaitu keharaman melanggar kehormatan mayat, atau keharaman menganiaya dan mencincangnya. Nash yang lebih kuat ini, bertentangan dengan apa yang dikehendaki oleh 'illat masalah cabang (transplantasi organ), yaitu kebolehan melakukan transplantasi. Berdasarkan dua hal di atas, maka tidak dibolehkan mentransplantasikan organ tubuh yang menjadi tumpuan harapan penyelamatan kehidupan -seperti jantung, hati, dua ginjal, dua paru-paru- dari orang yang sudah mati yang terpelihara darahnya (ma'sbum al-dam). ${ }^{21}$

Namun demikian, secara umum sebenarnya kondisi dharurat (yang membahayakan) harus dihilangkan sebagaimana disebutkan dalam kaidah : الضرر يز ال "kemudharatan itu harus dibilangkan."22

Begitu juga dengan kaidah الضرر يدفع بقدر الامكان "kondisi dharurat ditolak semampu mungkin".

Jika pada kaidah pertama berlaku dalam segala permasalahan dimana unsur mudharatnya sudah terlanjur terjadi. Titik tekan pada kaidah kedua ini berdasarkan konsep mashlahah mursalah ${ }^{23}$ dan siyasah

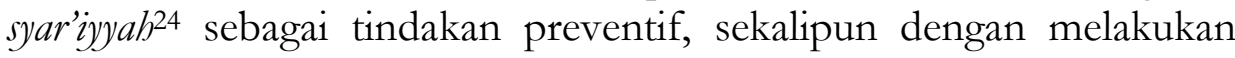
hal-hal yang terlarang sebagaimana yang tertuang dalam kaidah: الضرورة "kondisi dharurat membolehkan hal-hal yang terlarang".

${ }^{21}$ Lebih jauh lihat Abdul Qadim Zallum, Hukmu Asy Syar'i fi Al Istinsakh, Naqlul A'dlaa, Al Ijhadl, Athfaalul Anabib, Ajbizatul In'asy Ath Thibbryah, Al Hayab wal Maut, ( Beirut: Ummah, 1418/1997)

${ }^{22}$ Bunyi teks kaidah ini biasa digunakan mayoritas ulama penulis kitab fiqh mazhab al-Syafi'i sebagai kaidah induk yang membawahi beberapa kaidah lainnya Namun salah seorang intelektual dan faqih kontemporer, Muhammad Shidqi bin Ahmad al-Burnu, ternyata menempatkan kaidah ini hanya sebagai sub kaidah bukan kaidah induk. Karena menurutnya hanya mencakup furu' yang dhararnya telah terjadi. Lihat Muhammad Shidqi bin Ahmad, Al-Qawaid al-Wajiz fi Idlah Qawaid al-Fiqh al-Kulliyah, (Beirut: Mu'assasah al-Risalah, 1983), cet. 1, hlm. 77-78

23 Abdul Karim Zaidan, al-Wajiz, fi Ushul al-Fiqh, (Beirut: Mu'assasah alRisalah, 2001), Vol. VII, hlm. 237

${ }^{24}$ Muhammad Shidqi al-Burnu, Al-Qawaid al-Wajiz..., hlm. 80 
Dengan demikian, transplantasi yang pada dasarnya dilarang, tetapi di saat kondisi dharurat dapat dilaksanakan. Lebih jauh persoalan transplantasi dan donor organ tubuh lebih tepat kiranya ditengaral dengan menggunakan pendekatan istishlabi.25 Seluruh hukum yang ditetapkan oleh Allah SWT atas hambanya baik dalam bentuk perintah maupun dalam bentuk larangan adalah mengandung mashlahah. Mashlahah menurut al-Khawarizmi adalah: الحافظة على مقصود “ memelihara tujuan syara' (dalam menetapkan bukum) dengan cara menghindarkan kerusakan dari manusia". 26

Al-Syathibi mengartikan mashlahah itu dari dua pandangan, yaitu dari segi terjadinya mashlabah dalam kenyataan dan dari segi tergantung hukum syara' kepadanya. Dari segi terjadinya mashlabah dalam kenyataan, berarti: "Sesuatu yang kembali kepada tegaknya kebidupan manusia, sempurna bidupnya, tercapai apa yang dikehendaki oleh sifat syahwati dan, aklinya secara mutlak". ${ }^{27}$

Dalam perkembangan pemikiran ushul fiqh, corak penalaran istishlabi ini tampak dalam beberapa metode ijtihad, antara lain dengan mashlahah al-mursalah dan sad al-zariah. Masblabah al-mursalah menurut Muhammad Abu Zahrah adalah: "Maslabah yang selaras dengan tujuan syariat Islam dan tidak ada petunjuk tertentu yang membuktikan tentang pengakuannya atau penolakannya." 28 Sedangkan sad al-zari'ah menurut al-

${ }^{25}$ Corak penalaran istishlahi adalah upaya penggatian.hukum yang bertumpu kepada prinsip-prinsip kemaslahatan yang disimpulkan dari al-Quran dan al-Hadits. Lihat, Asafri Jaya Bakri, Konsep Maqashid Syari'ah Menurut aLSyathibi, Jakarta : PT Raja Grafindo Persada, 1996), hlm. 133

${ }^{26} \mathrm{Al}-$ Syaukani, Irsyad at-Fuhul ila Tahqiq al-Haqq min 'ilm al-Ushul, (Beirut : Dar Ibnu al-Haim, 2004), hlm. 447

27 Al-Syathibi, Al-Muwafaqat, II, Op-Cit, hlm. 16

28 Muhammad Abu Zahrah, Ushul al-Fiqh, (Kairo: Dar a]-Fikr al-Araby, 1958), hlm. 221.
Syathibi adalah: "Segala yang membawa kepada sesuatu yang terlarang, yang mengandung mafsadah (kerusakan)."29

Dengan memahami ke dua metode tersebut, persoalan-persoalah fiqh yang sifatnya ijtihadiyah dapat dikembalikan kepada kedua metode ijtihad tersebut. Mengacu kepada penjelasan ini, dalam hubungannya dengan transplantasi dan donor organ tubuh, dapat dipahami bahwa masalah transplantasi sepanjang itu membawa kemaslahatan apa pun bentuknya dapat dibenarkan oleh syara'.

Dengan demikian, kebolehan untuk melakukan transplantasi dan donor organ tubuh, dapat merujuk kepada tujuan universal penciptaan manusia yaitu sebagai khalifah $f i$ al-ardh sebagaimana dijelaskan dalam Surat al-Baqarah ayat 30; "Dan (ingatlah) ketika Tubanmu berfirman kepada para malaikat, "Aku hendak menjadikan khalifab" di bumi."

Untuk dapat mewujudkan tujuan tersebut, perlu merekonstruksi bahkan dekonstruksi formula dharury yang selama ini dipahami sebagai sesuatu yang paling minimal yaitu yang membuat orang bisa bertahan hidup. Karena itu, - menurut formula ini - orang buta belum dikategorikan dharurat karena dia masih dapat menjalani hidup dengan kebutaannya, orang yang ginjalnya tidak berfungsi selama masih bisa hidup belum dikategorikan dharurat. Jika formula ini yang diterapkan, maka apapun upaya yang berhubungan dengan "perbaikan" tubuh tidak dianggap sebagai kewajiban. Namun demikian, bila merujuk kepada konsep khalifah fi al-ardh, upaya perbaikan dan penyempuraan fisik wajib dilakukan termasuk melakukan trasplantasi dan donor organ tubuh. Hal ini diperkuat dengan beberapa kaidah mashlahah sebagaimana disebutkan oleh alThufy sebagai berikut : [a]. Suatu ungkapan dalam Alquran, hadis, atau ketentuan hukum dalam kitab fiqh klasik yang dipertimbangkan adalah keumuman tujuan hukum, bukan bergantung kepada ketentuan teks statis atau sebab; [b]. Kepentingan umum adalah dalil hukum yang kehujahannya mandiri, tak bergantung kepada konfirmasi teks atau
${ }^{29}$ Al-Syathibi, al-Muwafaqat IV, Op-Cit, 113-114 
nash; [c]. Akal mempunyai otoritas untuk menentukan baik dan buruk (mashalih dan mafasid), tanpa bergantung kepada teks; [d]. Kepentingan umum adalah hujah hukum yang terkuat; [e]. Lapangan pemberlakuan rasionalitas maslahah adalah bidang hubungan antara manusia dan tradisi, bukan aturan ibadah kepada Allah. ${ }^{30}$

\section{Kesimpulan}

Berdasarkan uraian dan pembahasan di atas, patut diakui bahwa persoalan transplantasi organ tubuh bukanlah perkara sederhana, sehingga wajar jika para ulama berbeda pendapat tentang hukumnya, yaitu antara yang membolehkan dan menentangnya dengan argumentasi masing-masing. Kebolehan melakukan transplantasi dan donor organ tubuh secara umum merujuk kepada tujuan penciptaan manusia yaitu untuk menjadi khalifah fi al-ardh. Secara teknis dilakukan dengan penalaran ta'lili dan istishlabi. Secara ta'liliyah kebolehan transplantasi dan donor organ tubuh menganalogikan dengan kebolehan memberi maaf dan mengambil diyat pada kasus kisas. Secara istishlabiyah masalah tersebut ditengarai dengan konsep mashlahah yaitu sesuatu yang kembali kepada tegaknya kehidupan manusia, sempurna hidupnya, tercapai apa yang dikehendaki oleh sifat syahwati dan aklinya secara mutlak.

Di sisi lain pendapat yang mengharamkan transplantasi mengingatkan kita akan kemuliaan derajat manusia, baik ketika dia masih hidup bahkan sesudah mati sekalipun. Juga dengan mempertimbangkan posisi manusia sebagai hamba Allah yang hanya menerima titipan dan amanahNya, tidak memiliki secara mutlak terhadap diri dan hartanya sehingga ia dilarang merusak diri baik ketika hidup apalagi setelah kematian. Namun terlepas dari apapun pendapat yang dipilih oleh seorang ulama mujtahid, kebutuhan manusia terhadap transplantasi nampaknya tidak akan terbendung lagi.

${ }^{30}$ Dikutip dari, Wahbah al-Zuhaily, Ushul al- Figh al-Islamy, (Beirur: Dar alFikr, 1996) jilid II, hlm. 817-818
Oleh karena itu pendapat mana yang akan diterapkan terpulang kepada suara hati nurani kita sebagai manusia yang hidup dalam bimbingan iman dan keyakinan hati, dengan konsekwensi kesiapan menerima segala akibat dari keputusan yang kita buat. Akhirnya dengan bertawakkal kepada Allah, penulis akhiri tulisan ini dengan harapan semoga bermanfaat adanya bagi keimanan dan ilmu pengetahuan kita.

\section{Bibliografi}

Amidi, Al-Ihkam fi Ushul al-Ahkam, (Beirut: Muassasah al-Halaby, 1991).

Anonim, Organ Transplant, Available at: http://www.en.wikipedia.com (Accessed: May 27, 2008)

Bakri, Asafri Jaya, Konsep Maqashid asy-Syari'ah Menurut asy-Syatibi, (Jakarta: PT Grafindo Persada, 1990).

Ghazali, Al-Mustashfa min Ilm al-Ushul, (Beirut: Dar al-Fikr, 1997).

Qarafi, Syarb Tanqib al-Fushul, (Kairo: Maktabah al-Kulliyyah alAzhariyyah, t.th).

Syathibi, Al-Muawafaqat fi Ushul al-Syariah, (Beirut: Dar al-Kutub alIlmiyyah, t.th).

Syaukani, Irsyad al-Fubul ila Tahqiq al-Haqq min 'Ilm al-Usbul, (Beirut: Dar Ibnu al-Halm, 2004).

Teresa, L. Nilai Etika Transplantasi Organ. Dalam http://www./maranatha.com/transplantasi (Accessed: May 30, 2008)

Triana, N. Menengok Transplantasi Organ di China, Available at: http://www.jurnalnasional.com (Accessed: May 29,2008)

Undang-undang Republik Indonesia No.23 Tahun 1992 tentang Kesehatan. 
Haswir, Hukum Mendonorkan dan Mentransplasikan Anggota Tubuh ...

Zahrah, Muhammad Abu, Ushul al-Figh, (Kairo: Dar al-Fikr al-Araby, 1958).

Zaidan, Abdul Karim, al-Wajiz fi Ushul al-Fiqh, (Beirut: Mu'assasah alRisalah, 2001).

Zallum, Abdul Qadim, Hukmu Asy Syar'i fi Al Istinsakh, Naqlul A'dlaa', Al-Ijhadl, Athfaalul Anabib, Ajbizatul In'asy Ath Thibbiyah, Al Hayah wal Maut, (Beirut: Ummah, 1997).

Zarkasyi, al-Bahr al-Muhith, (Kuwait: Wizarat al-Auqaf wa al-syu'un al-Islamiyyah, 1993). 